\title{
EDITORIAL
}

\section{Jornal de Pneumologia: agora também on-line}

\author{
www.jornaldepneumologia.com.br
}

Em geral, as revistas científicas on-line limitam-se a reproduzir os artigos impressos. Têm, entretanto, rapidez na colocação dos trabalhos na rede mundial - muitas vezes precedendo em tempo significativo o número impresso -, permitem acesso fácil a um extenso banco de dados e economizam espaço nos armários.

Recentemente, algumas revistas como Science e $\mathrm{Na}$ ture modificaram este perfil de edições on-line apenas reprodutivas, tornando os textos on-line mais completos e mais extensos, publicando alguns trabalhos somente online, etc. O American Journal of Respiratory and Critical Care Medicine, a partir de outubro de 2000, também promoveu modificações na sua edição on-line. Assim, a seção de Materiais e Método, que por razões econômicas $e ́$, em geral, curta e, conseqüentemente, quase sempre incompleta, às vezes ininteligivel e os métodos nem sempre são reproduziveis por falta de informações, passou a ser bem detalhada na versão on-line. Outra inovação é a disponibilidade na edição on-line dos artigos poucos dias após a aceitação, evitando os atrasos de informação causados pela grande demanda de trabalhos que aguardam impressão. Por isso, atualmente, para se submeter um manuscrito para publicação no AJRCCM são mandatórias duas versões: uma para a edição impressa e outra para a edição on-line. O Editor, Martin J. Tobin ${ }^{(1)}$, explica esta obrigatoriedade em um interessante Editorial intitulado "Authors, Authors, Authors - Follow instructions or expect delay" (Autores, Autores, Autores - Sigam as instruções ou esperem por atraso). Esta frase deve embalar os sonhos de todos os Editores de revistas científicas!

E, como alguns sonhos se realizam, o Jornal de Pneumologia inicia o terceiro milênio também on-line no site www.jornaldepneumologia.com.br, que ficará com acesso livre até julho de 2001. Depois desta data, o acesso aos artigos completos será restrito aos sócios da SBPT, através de senhas. Para outros visitantes somente os resumos ficarão disponiveis. O site tem também uma versão em inglês com informações sobre a revista, instruções redatoriais e abstracts, podendo ser encontrado por pesquisa feita em inglês usando as palavras Brazilian, Journal, Pneumology. Assim, a comunidade internacional de língua não portuguesa poderá nos conhecer e ter acesso aos nossos trabalhos.
Graças ao esforço dos antigos Editores na conservação do patrimônio da revista todos os volumes estão sendo colocados on-line e os artigos poderão ser encontrados pelos títulos, pelos nomes dos autores e/ou pelos descritores. Como o Jornal de Pneumologia tem 27 anos, e neste período o processo de impressão sofreu muitas modificações, não foi possivel padronizar a apresentação dos artigos mais antigos. Isto só pode ser feito com aqueles publicados a partir de 1999 (vol 25). Todavia, como a forma não altera o conteúdo, não houve prejuízos irreparáveis. As técnicas atuais de diagramação, de impressão e de linguagem de computação permitirão a manutenção da padronização no futuro.

Nesta fase de implantação da edição on-line vamos apenas reproduzir os artigos impressos. Para atingirmos o grau de perfeição on-line das revistas científicas de grande impacto precisamos da compreensão dos autores no respeito às normas da revista. Assim, quem sabe, nosso processo de editoração fique mais rápido e possamos colocar a edição on-line antecedendo a edição impressa. Para nos fazermos respeitados pela comunidade internacional precisamos despertar o interesse de leitores que não falem português e para isso os abstracts devem ser estruturados, resumindo adequadamente o trabalho em inglês fluente e inteligível.

Esperamos, portanto, servir aos sócios da SBPT, despertar o interesse de colegas de outras especialidades $e$ manter um contato mais estreito com a comunidade científica internacional. Para aperfeiçoarmos este processo precisamos das opiniões, das críticas e das sugestões de nossos leitores.

Veja o Jornal de Pneumologia on-line. No site há um espaço para manifestações, as quais aguardamos com ansiedade.

\section{REFERÊNCIA}

1. Tobin MJ. Editorial: Authors, authors, authors - follow instructions or expect delay. Am J Respir Crit Care Med 2000;162:1193-1194. 